Nadwa | Jurnal Pendidikan Islam

Vol. 10, Nomor 2, Oktober 2016

\title{
Madrasah Culture Based Transformational Leadership Model
}

Nur Khoiri

UIN Walisongo Semarang
nur_khoiri@yahoo.co.id

Abstract

Leadership is the ability to influence, direct behaviour, and have a particular expertise in the field of the group who want to achieve the goals. Dynamic organization requires transformational leadership model. A school principal as a leader at school aims to actualizing good learning leadership. Leadership learning focuses on learning which components include curriculum, teaching and learning process, assessment, teacher assessment and development, good service in learning, and developing a learning community in schools based on organizational culture as value, assumption, belief evolved from the roots of member thought of the organization and believed by all members of the organization and implemented in everyday life that could give meaning Keywords: leadership, transformational leadership, headmaster, instructional leadership, organizational culture.

\section{Abstrak}

Kepemimpinan merupakan kemampuan mempengaruhi, mengarahkan tingkah laku dan memiliki keahlian khusus di bidang yang diinginkan kelompoknya untuk mencapai tujuan. Oganisasi yang dinamis memerlukan model kepemimpinan transformational. Kepala sekolah sebagai pimpinan memiliki tujuan untuk mewujudkan kepemimpinan pembelajaran yang baik. Kepemimpinan pembelajaran memfokuskan pada pembelajaran yang komponen-komponennya meliputi kurikulum, proses belajar mengajar, assesment (penilaian hasil belajar), penilaian serta pengembangan guru, layanan prima dalam pembelajaran, dan pembangunan komunitas belajar di sekolah berbasis budaya organisasi yang berupa nilai, asumsi, kepercayaan yang berkembang dari akar pemikiran anggota organisasi dan diyakini oleh semua anggota organisasi serta dilaksanakan dalam kehidupan sehari-hari .

Kata kunci: kepemimpinan, kepemimpinan tranformational, kepala sekolah, kepemimpinan pembelajaran, budaya organisasi. 


\section{Introduction}

In group of people, communities and organizations, the presence of a leader is a necessity that cannot be abandoned. Leaders work with its members to achieve the goals outlined by the organization, according to the vision and mission of the organization. A leader controls and directs their members to achieve the goals maximally.

Leadership requires good organizational requirements and prerequisites for moving the process of leadership in order to get maximum results. One of the leadership principles proposed by Reinhartz \& Beach is the leadership must use the knowledge of core values, which becomes a bond between the leader and members, or among members in an organization to achieve the goal.

School is an educational organization that cannot be released from formal leadership. The school principal is a leader in charge of teachers, staff, and students in leadership learning process. Each school principal has various leadership models, depending on the personal character of the members, community culture where the school is located, as well as goals to be achieved by the school.

Each organization cannot be separated from the individual culture within the organization. In a broader context, individuals gain the knowledge and values of the society that goes down continuously through the generations. The community values help shaping how the process takes place in an organization's leadership.

Leadership-based organizational culture is one form of leadership concept that can be implemented by the principal in leading the learning process at school. Organizational culture in schools involves school principals, teachers, and staff, so that students at the school get an excellence service of the learning process. 


\section{Definitions And Theory Of Leadership}

There are many definitions of leadership according to the circumstances and demands of the times. Moejiono states that the actual leadership is a result of one-way influence because the leaders may have certain qualities that distinguish themselves from their members. ${ }^{1}$ According Tead; Terry; Hoyt $^{2}$ leadership is an art of activity which influences others to cooperate based on the person's ability to guide others in achieving the desired goals of the group.

Leadership is the ability to influence people or groups in a purpose to achieve a goal or for other reasons. This is aimed at achieving both individual and others purposes. Moreover, the individual purposes could be same or different from the organization objectives. While Stephen P. Robbins, explains that leadership is the ability to influence a group toward the achievement of targets. ${ }^{3}$

From the definitions above, it can be concluded that leadership is the ability to influence and direct the behavior of members or groups, and having the specialities in the areas desired by the group, in order to achieve the objectives of the organization or group.

Besides the developing its definitions, theories of leadership also have developed as follows:

${ }^{1}$ Moejiono Imam, Kepemimpinan dan Keorganisasian, (Jogakarta: UII Press, 2002), hlm.33

2 Kartini Kartono, , Patologi Sosial, Jilid I, (Jakarta : Rajawali, 2003), hlm . 42

${ }^{3}$ P. Stephen Robbin, Organizational Behavior. (England.: Prentice Hall. 2008), hlm.432 
1. Trait Theory

Scientific analysis of leadership focused on the leaders themselves. Trait theory was first developed in ancient Greece and Rome who thought that leaders were born, not made. This is known as "the greatma theory". This theory suggests that leadership effectiveness depends on the greatness of the leader character. "Trait" or characters include personality, social ability and physical superiority.

Followers of this theory believe in the character. A person who has good leadership qualities, can be an effective leader. Characters of a leader as proposed by Judith R. Gordon include some special abilities in: (1) Intellectual Ability (2) Personal Maturity (3) Education (4) Social and Economic Status (5) Human Relations (6) Intrinsic Motivation and (7) achievement drive.

2. Theory of Leadership Behaviors and Situations

Behavior leadership theory is a theory which examines leader behavior in increasing his leadership effectiveness. This leadership theory switches from someone who has the leading ability to how a person's behavior in leading effectively. A leader's behavior has two tendencies. First, consideration, is the tendency of leaders who describe an intimate relationship with a subordinate. Second, initiation structure is the tendency of a leader who provides limits to subordinates. This leadership theory comes with theory of leadership situation, that a leader must be a good diagnostic and should be flexible according to the development and maturity of subordinates.

3. Contingency Theory

Contingency theory states that there is no single optimum management system, but the system depends on the level of environmental changes. This system is called the organic system (as opposed to a mechanistic system). This system 
has several characteristics: a) The substance is a human, not a duty. b) Less emphasize on hierarchy. c) The structure of interconnected, flexible in a group. d) Togetherness in the values, beliefs and norms. e) Control yourself, the joint adjustment.

4. Behavioristik Theory

Behaviorism is one of the school of psychology that sees people only in terms of physical phenomena, and neglects the mental aspects. In other words, behaviorism does not recognize intelligence, talents, interests, and feelings of individuals in a learning process. In this theoretical approach, effective management occurs when there is an understanding of the work, and more oriented to people as actors.

Maslow explains that the individual has five basic needs; physical, security, social, esteem, and self-actualization needs. These needs will lead to a desire to meet it. While Douglas Mc Gregor the $\mathrm{X}$ and $\mathrm{Y}$ theory. Theory $\mathrm{X}$ views pessimistic in terms of employees and managers in changing the working conditions and making effective use of rewards and punishment to improve employee productivity. Y theory employees in terms optimistic view in which the manager needs to do a humanistic approach to the employees, challenging employees to excel, encourages personal growth and drive performance.

5. Humanistic Theory

This theory is based on humanitarian principles and characterized by the presence of an atmosphere of mutual respect and freedom. This theory is generally found in human nature as "motivated organism". Organization has structure and specific control system. The function of leadership is to modify the organization so that individuals are free to realize the potential motivations in meeting their 
needs and at the same time consistent with the objectives of the group.

In humanistic theories, there are three basic variables, namely; (1) the appropriate leadership and attention to the conscience of members with all the expectations, needs, and abilities, (2) organizations are well conceived in order to remain relevancy to its members, in addition to the interests of the organization as a whole, and (3) familiar and harmony interaction between the leadership with members to foster unity and oneness and live peacefully together.

6. Situational Theory

Situational theory is a refinement of the shortcomings of earlier theories in predicting the most effective leadership. In "situational leadership", effective leaders diagnose the situation, select effective leadership styles and apply them properly. An effective leader in this theory should be able to understand the dynamics of the situation and its ability to adjust to the dynamics of the situation. Four dimensions of situation are managerial ability, organizational character, working character and the worker character. All of them will dynamically impact the effectiveness of the one's leadership 4

7. Transformational Theory

The theory of transformational tries to "turn" back the theory of "trait" or the particular traits of a person so that he/she can be a leader. Robert House conveys leadership theory by suggesting that effective leadership is the use of dominance, having confidence, influencing and displaying

4 John Ivancevich, , M, Konopaske, \& Matteson. Perilaku dan Manajemen Organisasi. (Jakarta : Erlangga, 2008), hlm 213. 
high morality to increase charismatic levels. ${ }^{5}$ Transformational leadership is very effective because it combines two theories, namely the theory of "behavioral" and "situational" with their respective advantages. In other words, it combines production-oriented employee with a review of the situation and the strength of its charismatic.

Transformational Style leaders is suitable for a dynamic organization, which is concerned with the change and innovation as well as competing with other companies in the international scope. The main requirement of success is the presence of a leader who has charisma. ${ }^{6}$

\section{Ransformative Leadership In Learning}

School is an educational organization in which the principal acts as the leader. School is a place of learning for students, so the school leadership is learning leadership as well. Manifestations of transformational leadership in learning is a strategy to create a learning process that is designed with mature from planning, implementation, and evaluation of learning in school.

The school principal has some roles to play together, include as the educator, manager, administrator, supervisor, motivator, entrepreneur, and leader. The role of the principal as leader and, specifically, as an instructional leader, less gain proper portion. During this time, the principal busy with routine jobs of an administrative , meetings, and other non academic activities that so the time to study renewal and innovative

\footnotetext{
${ }^{5}$ John Ivancevich, , M, Konopaske, \& Matteson.Perilaku dan Manajemen ... hlm.213

6 John Ivancevich, , M, Konopaske, \& Matteson.Perilaku dan Manajemen ... hlm 214
} 
curriculum, teaching and learning, and assessment of student learning outcomes received less attention.

Learning Leadership is an act done with the intention of developing the principal productive work environment and satisfying for teachers as well and finally able to create conditions of increased students learning. ${ }^{7}$ While Daresh and Playco defines learning leadership in an attempt to lead teachers to teach better, which in turn can improve student learning achievement.

Petterson mentions the effective learning-leardership is (a) the principal disseminate and embed the content and meaning of the vision in his schoolwork well, (b) the principal engage stakeholders in the management of schools, (c) the principal support for the learning, (d) the principal monitoring the learning process so as to understand more deeply and realize what is going on inside the school, and (e) the principal's role as a facilitator so, in many ways he can know the difficulties of learning and help teachers in overcoming learning difficulties.

In addition, the principal is in charge of to provide a curriculum including the general and specific guidelines, together with the teachers understand and describe the educational goals include: general purpose, instructional purpose, curricular goals and specific objectives. The school principal together with the teachers understand the effective teaching and learning processes, prepare the programs curricular and extensive activities, included the annual program, develop teaching tools, scheduling and distribution of tasks, developing the evaluation system of learning, supervise the teaching and

${ }^{7}$ Eggen, Paul dan Kauchak, Don, Educational Psychology Windows on Classroom, Sixth Edition, (New Jersey : Pearson Prentice-Hall, inc, , 2004). Hlm.46 


\section{1 | Nur Khoiri}

learning process, draw up norms for successive grade of the classroom, develop a library as a science and a place to learn.

The school principal also expected to motivate teachers, by providing incentives to teachers in order to actively work according to specific procedures and methods so that the work goes smoothly to reach the target. The motivating and activating together with the increasing of teachers' welfare is believed to provide encouraging results. That welfare can be partially realized through activities to motivate and activate. ${ }^{8}$ While Mattiuck states that school leadership is characterized by careful attention to the quality of teaching. The emphasis is on how principals do its work, so that teachers can carry out the teaching of the highest quality. ${ }^{9}$

The main purpose of learning leadership is to provide excellent service to all students so that they are able to develop the potential of the quality of basic and instrumental qualities to face the unknown future and laden with very turbulent challenges. According to Slamet PH basic qualities include the quality of the intellect, heart, and physical power / raga. The power of thought include ways of inductive, deductive, scientific, critical, creative, innovative, lateral, and systems thinking. Emotional powers (qolbu) include compassion, empathy, courtesy, honesty, integrity, discipline, cooperation, democracy, humility, peace, respect for others, responsibility, tolerance, and unity and the unity (too many to be called everything). Physical resources include health, kestaminaan, endurance, and skill.

Besides, learning leadership attempt to get a leader with an instrumental quality, which includes mastery of science and technology and the arts. Science can be classified as soft

${ }^{8}$ Made Pidarta, , Landasan Kependidikan (Jakarta : Rieneka Cipta, 2005) hlm. 45

${ }_{9}$ Moejiono Imam, Kepemimpinan ... hlm.81-82 
sciences (sociology, politics, economics, education, anthropology, and the like). Hard sciences include math, physics, chemistry, biology, and astronomy. Technology covers construction technology, manufacturing, transportation, telecommunications, energy, bio and materials. Art consists of sound art, music, dance, crafts, and such.

The learning and achievement of students should always be analyzed on an ongoing basis and reflected as well developed as part of school life. Such activities should be cultivated in the school. Based on research conducted by Glathhorn (1993) found five things that are important in shaping the culture of the school to train students for success in learning and also a healthy school climate, they are a) the school as a community and collaborative learning community, b) there is a shared belief to achieve the goal, c) school improvement is achieved through the troubleshooting process, d) the entire school community whether the principals, teachers and students to be convinced can achieve the goals, and e) learning is a key priority.

In connection with the functions of the climate of the school, the behavior of the principal following the most widely identified by teachers from schools which have the achievement of high academic achievement: 1) communicate to staff about the high expectations for students achievement, 2) prevent the school to pressure burden necessary, and to make learning as the main focus of school activities, 3) personally know about the level of professionalism of each teacher as a basis for achieving the main goal of the school, 4) assess the morale and commitment of the school community, and 5) build a safe, order and discipline school environment.

\section{Core Values As Joint Cultural Organization In School}

People's daily lives cannot be separated from the created cultural ties. Cultural ties are created by the people, whether in 
families, organizations, businesses and nations. Culture distinguishes people from one another in how to interact and act a complete job. Culture binds members of the community into one unified view of creating uniformity behavior or performance. The culture must have formed within the organization and can also be perceived benefits in contributing to the effectiveness of the organization as a whole.

Culture leads to behaviors and beliefs. The statement is best supported by the definition of organizational culture by Davis and Newstrom in Mangkunagara (2005) who argued that "Organizational culture is the set of assumptions, beliefs, values, and normas that is shared among its members".

Jones (2008) revealed the organizational culture as "The set of shared values and norms that controls organizational members interaction with each other and with people outside the organization", which means that the organizational culture is a set of shared values and norms to control the interaction between members of the organization and with people outside the organization.

While Robbins ${ }^{10}$ says that organizational culture refers to a system of shared-value held by members and differentiates one organization to another. Schein defines organizational culture as an operational nature:

The culture of a group can now be defined as a pattern of shared basic assumptions that the group learned as it solved its problems of external adaptation and internal integration, that worked well enough to be considered valid and, therefore, to be taught to new members as the correct way to perceive, think, and feel in realtion to those problems.

${ }^{10}$ P. Stephen Robbins, 2008. Organizational... 
According to Wood, Wallace, Zeffane, Schermerhorn, Hunt, Osborn it is the organizational culture and value system that is developed by the organization where it leads the behavior of members of the organization itself. Tosi, Rizzo, Carroll argues organizational culture are ways of thinking, feeling and reacting based on certain patterns that appear within the organization, or that exist in parts of the organization. Organizational culture is a common perception held by members of the organization.

Schein (1992) argues that organizational culture is the basic patterns received by the organization to act and solve problems, form the staff who are able to adapt to the environment and unite the members of the organization. It must be taught to new members as the correct way to assess, think and encounter the problems.

According Cushway and Lodge (GE, 2000: 25) the organizational culture is a system of values of the organization and affect the work way and how employees behave. It can be concluded that the definition of organizational culture in this study is the value system of the organization held by members of the organization, which then affects the way to work and behave of the organization members.

It can be concluded that organizational culture is the values, assumptions, beliefs evolved from the roots of thought of the organization members and it is believed by all organization member and implemented in everyday life that can give meaning so, the organization different from the others.

According to Robbins ${ }^{11}$ there are five characteristics or dimensions of organizational culture, they are: (1) Innovation and risk-taking. The extent to which employees are encouraged to be innovative and take risks. (2) The detail attention. The

${ }^{11}$ P., Stephen Robbins, 2008. Organizational...hlm. 721 
extent to which employees are expected to demonstrate rigor analysis and attention in detail. (3) Orientation results. The extent to which the management focus on results rather than the techniques and processes used to achieve those results. (4) Orientation people. The extent to which management decisions take into account in effecting people within the organization. And (5) Orientation team. The extent to which work activities are organized around teams, rather than individuals.

How can organizational culture built and maintained, according to Robbins ${ }^{12}$ described in the following figure:

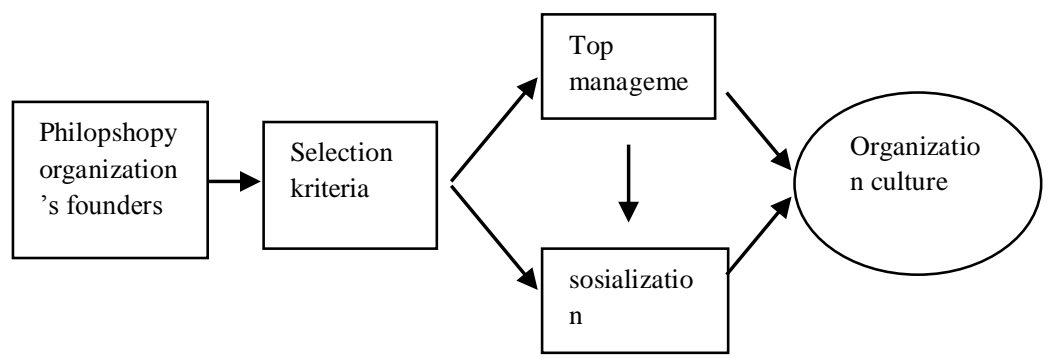

Chart formation of organizational culture ${ }^{13}$

The formed organizational culture is determined by several elements, namely: (1) the business environment; the environment, in which it operates, determine what should be done by the company to achieve success. (2) values (values); the basic concepts and beliefs of an organization. (3) a model; people become exemplary role models or other employees because of his success. (4) ceremonies (rituals); routine events

${ }^{12}$ P., Stephen Robbins, 2008. Organizational.. hlm.734

${ }^{13}$ P., Stephen Robbins, 2008. Organizational...hlm.734 
organized by the company in order to reward employees. And (5) "network"; informal communication network within a company can be a means for distributing the values of the culture.

After understanding the concept of organizational culture as mentioned above, the application of organizational culture in the context of schooling will be described further. In general, the application of the concept of organizational culture in schools is actually not much different from the application of the concept of organizational culture. By regarding organizational culture at school of Paul E. Heckman, as quoted by Stephen Stolp argues that "the community helds beliefs of teachers, students, and principals."

The values developed in school, of course, cannot be separated from the existence of the school itself as an educational organization, which has the role and function in trying to develop, preserve and pass on cultural values to their students. In this case, Larry Lashway (1996) states that "schools are moral institutions, designed to promote social norms, ..."

The values that may be developed in school is certainly very diverse. When referring to Spranger thought as presented by Sumadi Suryabrata ${ }^{14}$, there are at least six types of values that should be developed in school. In Table 1 the following proposed Spranger's six types of value and its essential behavior.

Table 1

Type Values and Essentials Behavior by Spranger

\begin{tabular}{||c|l|c||}
\hline \hline No & \multicolumn{1}{|c|}{ Value } & Basic behavior \\
\hline \hline 1 & Science & Thinking \\
\hline 2 & Economy & Works \\
\hline \hline
\end{tabular}

${ }^{14}$ Sumadi Suryabrata. Psikologi Kepribadian.(Jakarta: Rajawali. 1990). Hlm.56 


\begin{tabular}{||c|l|c||}
\hline \hline 3 & Art & Enjoy the beauty \\
\hline 4 & Religious & Worship \\
\hline 5 & social & Filial / sacrifice \\
\hline 6 & Politics / state & In power / reign \\
\hline \hline
\end{tabular}

Source: Modified by Sumadi Suryabrata. ${ }^{15}$

With reference to the thought of Fred Luthan, and Edgar Schein, the following described the characteristics of organizational culture in the school; (1) observed behavioral regularities; (2) norms; (3) dominant value. (4) philosophy; (5) rules and (6) organization climate.

First, Observed behavioral regularities; organizational culture in schools is characterized by regularities way of acting of the entire membership of the school that could be observed. The behavior regularities can take the form of certain rituals, the common language used or the specific symbols, which reflect the values held by members of the school.

Second, Norms; organizational culture in the school is also marked by the norms which contains the standard behaviors of school members, both students and teachers. The standard behaviors may be based on the internal policies of the school itself and the policies of local governments and the central government. Standard of students' behavior, especially related with student achievement, which determines whether a student can be passed or not. Standard behavior of students does not only happened by respecting to cognitive or academic aspect itself, but also involve all aspects of the personality.

Third, the dominant values; Values and beliefs about the attainment of the quality of education in schools should be the main thing for the entire school community. As for the meaning of the quality of education itself, Jiyono defines it as an

${ }^{15}$ Sumadi Suryabrata. Psikologi ...hlm.105 
overview of educational success in changing the behavior of the students associated with educational goals. Ministry of Education in Year 2001 describes the quality of education included the aspects of input, process and output of education. In the aspect of input, the quality of education is shown by the level of readiness and availability of resources, software, and expectations. The higher the level of preparedness of the input means the higher the quality of the input. While the aspects of the process, the quality of education is shown through coordination and harmonization as well as directing the schools' input conducted in harmony, so as to create a pleasant learning situations (enjoyable learning), able to encourage the motivation and interest in learning, and really be able to empower learners. Meanwhile, from the aspect of output, quality of education can be seen from the performance of the school, especially student achievement, both in academic and nonacademic.

Fourth, philosophy; organizational culture characterized by the belief of all members of the organization in view something essentially, for example about time, man, and so forth, which serve as the organization's policy. If we adopt the philosophy in the world of business that has proven to give the advantage to the company, this philosophy is put on the efforts to provide satisfaction to its customers, then the school should also have a belief in the importance of efforts to provide customer satisfaction. In the context of the School-Based Quality Improvement Management, Ministry of Education argues that:

"Customers, especially students must be the focus of all activities in the school. That is, all input- processes deployed in schools focused primarily on improving the quality and satisfaction of learners. The logical consequence of all this is that the input setup, the learning process should be truly 
embodies the whole figure expected quality and student satisfaction."

Fifth, rules; organizational culture is characterized by the provisions and rules that are binding on all members of the organization. Each school has specific provisions and rules of the game, whether they are from the local school policy, and from the government, which is binding on the entire school community to behave and act in the organization. The general rule in this school is packaged in the form of a the school Code of Conduct (school discipline), in which contains about what should and should not be done by the school community, as well as equipped with provisions of sanctions if any wrongdoing. Joan Gaustad (1992) in his writings on School Discipline, published in ERIC Digest 78 says: "School discipline has two play goals: (1) Ensure the safety of staff and students, and (2) create a conducive learning environment.

Sixth, the organization climate; organizational culture characterized by their organizational climate. Hay Resources Direct (2003) argues that "organizational climate is the perception of how it feels to work in a particular environment. It is the "atmosphere of the workplace" and people's perceptions of "the way we do things here." Schools should be able to create a fun and conducive atmosphere in working environment for every member of the school through a variety of both physical and mental environmental regulations. In the context of School Based Quality Improvement Management, Ministry of Education (2001) argues, that one characteristics of MPMBS is a safe, good, and confortable environment so that teaching and learning can take place comfortably (enjoyable learning).

In view Reinhartz \& Beach (2004), the leadership in the 21 st century must use the shared knowledge of core values. This has actually become the spirit of the organizational culture in schools, in which all individuals in the school, whether the 
principal, teachers, staffs, and students must have shared knowledge of core values, in which at a later stage will produce what, by Robbins ${ }^{16}$ called, the culture that will give birth to a commitment to something larger than the individual interests.

\section{Analysis}

Leadership cannot be separated from the culture in the organization. Organizations, such as schools, contain of individuals (teachers and staff) with different cultural backgrounds, unique personality, egocentric personal interests, and other aspects of a challenge for school leadership. While the phenomenons, which are visible in the organization, are calmness, coolness, beauty, confidence, harmony. All of them do not only describe the leadership that exists in the organization, but also describe the culture in the organization. It could be said that seeing the leadership of an organization is the same as looking at cultures that exist within the organization. It looks like two sides of a coin that has the same value (Schein, 1991).

Members of the organization at school (teachers and staff) work based on the job descriptions that have been assigned to them. The job descriptions of the employees lead to the achievement of organizational goals and ultimately create the organization's mission. The organization's mission has been set by top management or owners based on the basic assumption they already have as they are building the organization or company where the culture created by the leader Thus, the leader also acts as initiator of culture to build the knowledgecore value.

Mc. Kinsey 7-S Framework suggests a model known as the model 7s of McKinsey. This model describes the relationship

${ }^{16}$ P., Stephen Robbins, Organizational... 
between the leader, organizational culture, and strategy. Mc. Kinsey explained that the strategy that have been agreed upon by the leaders should be supported by the organizational structure and system which is applied in the organization. The structure and the system is determined by the leader's style. The leader determines who the person who help him (Staff), and the skills possessed by staff. Structure, systems, style, staff, and skill have contributed to the success of the strategy. The contribution of $5 \mathrm{~s}$ (structure, systems, style, staff, and skills) is called Shared-value or known as cultural organizations.

School is a dynamic organization, where principals, teachers, and staff engaged in a pattern of cooperation that is constantly changing. Teachers and staff are human beings who have feelings, emotions, and attention as well as an interest in a job that is up and down. Therefore, it is necessary to build a culture to bear a larger commitment than individual interests. Leadership strategies and models need to choose the most effective leadership and allows to get the maximum possibility.

The effective leadership theory used is the theory of transformational because, the school is a dynamic organization. This Transformational leader's style is suitable for a dynamic organization which is concerned with the change and innovation as well as competing with other schools within the scope of local, national, and international. In addition, the transformational leadership requires the charisma of a leader so the teachers and staff respect and obey the leader instruction. A charismatic leader tends to be easier to organize its members. Thus, the concept of transformational leadership is a leadership model based on organizational culture in the school.

Transformational leadership will bring forth a transformative leader with qualities of a leader, organizing and mobilizing effective management, being humanistic, and has the ability to read the situation. That is, the transformative leaders 
will continue to adapt to potential members and create policies that correspond to the situation at hand. Transformative leader is not afraid of change that occurs continuously, always transforming the values and ideas to its members to be ready to face the challenge.

\section{Conclusion}

From the above explanation, it can be concluded that the leadership in any organization, including organizations such as school education is essential in achieving organizational objectives in schools, especially those related to learning. Principals should have instructional leadership, and prepare learning programs with the teachers to improve student achievement.

The principal as leader has the responsibility of leadership in the organization he leads. Principals can choose the style of leadership in accordance with the culture of its members (teachers and staff). Transformational leadership is the most effective leadership model in order to strengthen the leadership model based on culture.

Leadership based organizational culture can be applied in schools. The success of leadership based organizational culture requires a blend of leadership, organizational culture, and strategy. Leaders must choose the right skilled-staff to achieve the goal. Structure, systems, style, staff, and the ability of members of the components make up the shared values known as organizational culture.

\section{Bibliography}

Eggen, Paul dan Kauchak, Don, 2004. Educational Psychology Windows on Classroom, Sixth Edition, Pearson PrenticeHall, inc, New Jersey 
173 | Nur Khoiri

Imam, Moejiono, 2002, Kepemimpinan dan Keorganisasian, Jogakarta, UII Press

Ivancevich, John, M, Konopaske, \& Matteson. 2008. Perilaku dan Manajemen Organisasi. Jakarta : Erlangga.

Kartono, Kartini, 2003, PatologiSosial, Jilid I, Rajawali, Jakarta,

Ndraha, Talizuduhu. 1999, Pengantar Teori Pembangunan Sumber Daya Manusia. Jakarta: Rineka Cipta

Pidarta, Made, 2004, Landasan Kependidikan, Jakarta : Rieneka Cipta.

Robbins, P., Stephen, 2008. Organizational Behavior. Prentice Hall. England.

Sallis, E. (1993), Total Quality Management in Education, London: Kogan Page Limited.

Sastropoetro, Santoso. 1988, Partisipasi, Komunikasi, Persuasi, dan Disiplin dalam Pembangunan Nasional. Bandung: Alumni.

Schein, H., Edgard. 1992. An organizational Culture and Leadership. San Fransisco : Yossey Bass Publisher.

Sergiovani, 1987, The Principalship : A Reflective Practice Perspective, Boston : Allyn And Bacon, Inc.

Slamet Santoso, 1992, Supervisi Pengembangan Masyarakat, Bandung: PT. Enerco.

Slamet, Y. 1993, Analisis Kuantitatif Untuk Data Sosial. Solo: Dabara. Publisher.

Sobirin, Akhmad. 2007. Budaya Organisasi: Pengertian, Makna, dan Aplikasinya dalam Kehidupan Organisasi. 
Unit Penerbit dan Percetakan Sekolah Tinggi Ilmu Manajemen YKPN. Yogyakarta.

Soetomo, 2006, Strategi-Strategi Pembangunan Masyarakat, Yogyakarta: Pustaka Pelajar.

Starratt, R.J. 1996, Leaders with vision: The Quest for School Renewal, California: Crowin Press.

Sugiyono. 2011. Metode Penelitian Kuantitatif, kualitatif dan R \& D. Bandung: Alphabeta

Sumadi Suryabrata. 1990. Psikologi Kepribadian.Jakarta: Rajawali

James P. Spradley. 2007. Metode Etnografi. Yogyakarta: Tiara Wacana,

Stoner James A.F. 1986, Manajemen, Jilid II, Jakarta: Erlangga.

Judith Preissle \& LeCornpte, Margaret Diane, 1993, Ethnography and Qualitatif Design in education

Harsono. (2001). Latihan Kondisi Fisik. Bandung: Senerai Pustaka.

Sutjipto, 2003, Pendidikan Guru: Masalah dan Strategi Pemecahannya, Yogyakarta: Pustaka Pelajar.

Samsudin, Sadili. (2006). Manajemen Sumber Daya Manusia. CV. Pustaka Setia, Bandung.

Sugiyono, 2011, Penelitian Kuantitatif, Kualitatif dan $R \& D$, Bandung: Alfabeta.

Suparlan, YB. 1990, Kamus Istilah Kesejahteraan Sosial, Yogyakarta: Kanisius.

Suryadi, Ace. 1991. Biaya dan Keuntungan Pendidikan, Mimbar Pendidikan. No 1 Tahun X April 1991. Bandung: IKIP. 
175 | Nur Khoiri 